\title{
Barriers Influencing Organizations in Developing Country Not Appling Updated Strategic Management Techniques: A Case Study of Iran
}

\author{
Nima Noohpishe ${ }^{1} \&$ Elham Taghizadeh ${ }^{2}$ \\ ${ }^{1}$ School of Management, University of Tehran, Tehran, Iran \\ ${ }^{2}$ School of Industrial Engineering, Wayne State University, Detriot, USA \\ Correspondence: Elham Taghizadeh, School of Industrial Engineering, Wayne State University, Detriot, MI 48202, \\ USA.
}

Received: September 4, 2019

doi:10.5430/jms.v10n5p25
Accepted: September 25, 2019

Online Published: September 28, 2019

URL: https://doi.org/10.5430/jms.v10n5p25

\begin{abstract}
Although the advantages of utilizing enhanced strategic management tools have already been demonstrated in developing countries; but applying them for decision-making is still a challenge in practice for managers. In this study, we investigated why strategists and managers were not willing to apply these tools. In this paper, the Q statistical method was employed to define the barriers influencing not using these methods and to determine in Iran and how the managers' attitudes affected the outcomes. The study enrolled 43 strategists who were managers with high education levels. From secondary sources, we selected 68 Q statements from which 43 final Q statements were chosen by six strategic management experts. Following a binding algorithm, the participants sorted the $\mathrm{Q}$ statements. Utilizing factor analysis, the managers identified twelve main reasons (mental patterns) for lack of implementing new advanced strategic techniques in organizations. For instance, the study finds that most Iranian firms have a willingness to preserve traditional attitudes because they are disappointment with new tools; Some indicated that there is a lack of access to a successful model and resources. The finding this study, help strategist and managers to better understand how their attitudes and can affect the firm performance, and then follow the best strategy to improve their performance.
\end{abstract}

Keywords: strategy management, tools and techniques, q method, barriers to action

\section{Introduction}

\subsection{Introduce the Problem}

In recent years, strategic planning has been prioritized to the status of an essential and effective management tool in most companies. Strategic planning is not only a technical approach to planning but embodies an optimistic view that encourages managers to make plans for long-term growth and future competitiveness. In an organization where there is no such belief, strategic planning will not be given a proper platform for application. Strategic planning must have a tight relationship with the organization and its operation, and managers must take carefully thought-out actions to provide the best guidance for the workers who must implement the plans. In the currently challenging world market, an organization without strategic planning is like a ship without a rudder due to the turbulence of unpredictable events and environmental changes. Thus, employing strategic planning allows managers to be proactive in attempting to identify and circumvent future potential problems. It can help them to consider human capital, new technology and the changing commercial environment as a unique and interrelated unit (Kiran, 2017).

\subsection{Problem Statement}

The concepts of strategic planning have been brought to the forefront in most Iranian industrial units, and departmental managers strived to apply strategic planning as the best solution for the company's problems. In Iran, there have been several organizations attempting to use strategic planning techniques, but which failed to achieve the desired competitive advantages over other organizations. Choosing the right techniques among the variety of available tools has proved challenging for today's managers who must identify future company issues and implement strategic planning decisions to avoid them (Ramanujam. V, Venkatraman, N. and Camillus, J., 1986). Guidelines for strategic management can help managers at all stages of planning to improve performance in the organization-from how to conduct a thorough analysis to selection of the best approaches for improving competitiveness (Anna Afonina, 
and Vladimír Chalupský, 2012). This knowledge can aid managers in obtaining the information necessary to allow them to brainstorm with their employees on the most appropriate approaches for taking specific actions (Fleisher.G, and Bensoussan, B, 2003). Strategic planning benefits all employees by raising awareness of the importance of business environment, pinpointing strategic issues, identifying opportunities, and reducing risk in making decisions. These tools not only provide analytical capability, but also act as a valuable communication platform providing a framework for assessing the importance of diverse business portfolios and helping to simplify complex models (Frost, 2003).

Table 1. Definitions of strategic management techniques

\begin{tabular}{ll}
\hline Article & Definitions \\
\hline (Rigby, 2001) & $\begin{array}{l}\text { The management tool contains various concepts, processes, actions, } \\
\text { and analytical frameworks. }\end{array}$ \\
\hline (Rigby, 2005) & $\begin{array}{l}\text { The term "strategy tool" embraces concepts, ideas, techniques and } \\
\text { approaches that influence strategic planning, decision making, and } \\
\text { implementation. }\end{array}$ \\
\hline (Knott, 2006) & $\begin{array}{l}\text { Strategic tools can guide thinking and provide a starting point for } \\
\text { planning management activities. }\end{array}$ \\
\hline (Gunn, R. \& Williams,W., 2007) & $\begin{array}{l}\text { Strategic tools are used to simplify and illustrate a complex model. } \\
\text { The authors use "tools to incorporate every kind of systematic } \\
\text { approach that has been used for strategic decision-making". }\end{array}$ \\
\hline (Stenfors, S., Tanner, & L., \\
Haapalinna, I., 2004) & $\begin{array}{l}\text { Strategic tools are a mixed group of designed products to support } \\
\text { organizations in complex, competitive markets and for the creation } \\
\text { and maintenance of strategic advantages. }\end{array}$ \\
\hline
\end{tabular}

Over recent years, research has highlighted the usefulness of strategic tools and techniques by companies and industries in various countries. In the following list of articles, the authors provide guidelines to managers for effective use of strategic analytical tools:

(1) Webster et al. (1989) introduces 30 of the most well-known and used strategic planning tools. (Webster, J. L., Reif, W. E. And Bracker, J. S., 1989)

(2) Clark (1997) combines the strategic analysis method with the strategic management process. (Clark, D. N., 1997)

(3) Miles et al. (1997) demonstrates the conceptual usage and application of specific analytical tools in agricultural industries. (Miles, M. P., White, J. B., Munilla, L. S., 1997)

(4) Rigby (2001) explores the implementation of 25 strategic analysis management tools and illustrates the important interconnected part they play in the organizational process. (Rigby, 2001)

(5) R. P. Wright et al. (2013) shows that various business school just use different strategy tools and they did not care how they can appropriate to vision or mission (R. P. Wright et al., 2013).

\subsection{Strategy Planning}

The history of strategic planning can be divided into three phases: production-driven (1820), market-oriented (1900), and over-industrialized (1950) (Kohli, A K. \& Jaworski, B. J., 1990). The use of strategy in business is certainly not a new concept and has been employed for decades to gain market share and improve productivity (Henderson, 1989). An organization, like an individual, must have a strategy in its life implicitly or explicitly, in order to survive and function effectively, but the idea of a 'business strategy' has been in vogue for less than a century. Strategic planning was formally introduced as a set of methods in the market-oriented business stage and has been thoroughly developed during the over-industrialized phase. Many tools, employing quantitative and qualitative methods for strategic planning have been introduced and the role of the strategy expert, skilled in using these methods has grown considerably on corporate boards. In the literature, Henry Mintzberg provided a marketing strategy in ten subgroups and categorized them into three main groups: prescriptive, descriptive, and compilations. He also posited five strategic areas: plans, patterns, policies, positions, and perspectives (Mintzberg, H., Ahlstrand, B. \& Lampel, J, 1998; Mintzberg, 2007). Porter focused on the long-term advantage of creating a competitive strategy (Porter, 1996). while Gary Hamel 
emphasized broad spectrum strategic planning to meet all contingencies in an increasingly competitive environment (Hamel, 2006). There are some critics of current strategy concepts, however, who believe that planning and implementing strategy is simply not feasible in the volatile, unstable real-world business market of today (Kaye, 1996). Recently, a review paper looks through the 88 strategics articles and listed all tools that can help strategizes to planning and enhance their performances (Tero Vuorinen, 2017).

\subsection{Significance of the Study}

This research can fill the gap in a lack of studies to identify the reasons why managers of Iranian organizations fail to utilize advanced strategic management tools and extend the literature on updated strategy management tools to enhance firm performances. Q methodology was employed to investigate the variety of subjective barriers to strategic planning in Iranian organizations. The hypotheses developed and reviewed in the Q method are not considered quantitative because they are not based on the researchers' knowledge and beliefs about what they expect to be rejected or accepted, but rather on the mentality and subjective perceptions of individuals. This work applies a unique $\mathrm{Q}$ methodology approach that adds to the existing literature relating to strategy planning concepts regarding the question of why corporate managers in Iran fail to utilize strategic planning techniques.

The paper is organized as follows: first, the trends and evolution of strategic planning are briefly reviewed; in the next section, the Q method for identifying people's viewpoints in applying strategy planning tools is discussed. We explore the data and discuss our results in the following sections. In the last section, we offer our conclusions and discuss the implications and usefulness of the results.

\section{Theoretical Framework}

\subsection{Evolution of the Strategy Paradigm}

\subsubsection{Phase 1: Emergence of Strategic Planning}

Strategic planning is a systematic process that attempts to establish a long-term (three years or more) program for allocating resources and human capital to achieve well-defined goals (Oboreh J. S., \& Umukoro, F. G., 2011). The concept of strategic planning is very old but as an essential part of the business environment, its application grew rapidly in the 1960s and 1970s (Kohli, A K. \& Jaworski, B. J., 1990). The managers of a firm quickly saw the need for a comprehensive scheme to address environmental challenges and marketing changes, and the principles of strategic planning were seen to offer the best systematic method for accomplishing this. At that time, the business environment was more constant than today, so organizations were better able to make accurate long-term predictions. Strategic planning techniques burgeoned as every company sought ways to increase their market share and prevent common problems with labour, productivity and worker satisfaction. During this period, several tools were introduced for analysing the organizational environment - both internal and external - by management consulting firms and experts; such as SWOT, internal and external matrices, BCG and GE Matrix, SPACE, QSPM, CPM, and design, planning and positioning (Mintzberg, H., Ahlstrand, B. \& Lampel, J, 1998). After a decade or so, however, it became obvious that strategic planning alone did not always bring in the benefits and good outcomes expected by a company's managers and shareholders. The growing rapidity of change in the business environmental required a more agile and flexible approach to planning. While the traditional strategic business methods failed to preserve the organization from all challenges and issues, the basic concepts of strategic planning were still sound and studies were done to pinpoint the causes so the techniques could be improved (Pina e Cunha, M., \& Vieira da Cunha, J., 2006). Among the many possible reasons for failures in strategy, the most common was the continued application of traditional static strategy models to the challenges of a dynamically changing, multinational corporate ecosystem (Daniel, 2006). Strategists had focused only on known compilations that had been shown to work in the past and were believed to be adequate for the future. They were quickly proved wrong, however, and the application of strategic analysis for business planning entered a decline that lasted more than a decade (Gibson, 1998).

\subsubsection{Phase 2: The Emergence of the Balanced Score Card (BSC)}

The disappointing outcomes of strategic planning methods caused frustrated managers to reject their use until the early 1990s. It was eventually seen that one of the reasons for the lack of success in implementing the plans was the absence of a specific framework for executing the strategy (Okumus, 2003). To overcome this failure, Norton and Kaplan proposed the Balanced Score Card (BSC) in 1992 as a technique for achieving success in deploying strategic plans (Kaplan, R. S., \& Norton, D., 2008). In the BSC framework, financial indices are considered the conclusive indicators of success (Kaplan, R., \& Norton, D., 2006), although other criteria are also applied in determining long-term value for customers and establishing the necessary internal processes for continued learning (Kaplan, 2010). In fact, the BSC set 
a balance between short- and long-term objectives, internal and external phases, financial indexes and others (Kaplan, R., \& Norton, D., 2006). Hence, the BSC has quickly grown as a novel tool for strategic planning.

\subsubsection{Phase 3: The Emergence of Robust Strategy Methods}

In the 21st century, the greater level of uncertainty in the global business environment generated increased feelings of corporate vulnerability among strategists who felt compelled to develop and try new approaches and techniques (Oboreh, J. S., \& Umukoro, F. G., 2011). One of the current concepts behind the new planning methods is a focus on resilience--the capability of a system to maintain near optimal performance regardless of changes in operating conditions (Hammerstein, P., Hagen, E. H., Herz, A. V. M., \& Herzel, H., 2006). Another recognized goal for today's strategists is the making of robust planning decisions in response to evolving situations, such as conflicts or operational changes (Lempert, R. J., Popper, S. W., \& Bankes, S. C., 2003; 2010). When experience and insight are not sufficient guides because of the complexity of a situation, a concentration on sustainability in creating a workable plan will often be found to be the best option (Lempert, R. J., Popper, S. W., \& Bankes, S. C., 2010, Nomsa Sisi Majama, 2017). Robust decisions are usually part of a company's long-term strategy and may be based on a quantitative approach that integrates the capabilities of the workforce, human capital, equipment, and new technology. While the goals of traditional decision-making are to maximize the profits from tangible activities (Zacksenhouse, M., Holmes, P., \& Bogacz, R., 2008), sustainable decision-making incorporates an analytical framework for strategists and managers to apply new tools and methods to the traditional decision-making processes they are comfortable with (Lempert, R. J., \& Collins, M. T., 2007; Laamanen, 2017).

\subsubsection{Phase 4: The Emergence of Poised Strategy}

The fourth stage of strategic planning has been marked by the emergence of a new business paradigm which is usually referred to as the innovation economy. The innovation economy focuses on ways to achieve "profitability, value for competitive customers, efficient and effective business processes, and learning and growth goals". Companies that prosper in the innovation economy have learned to use their employees' shared knowledge and experience to generate new knowledge and make this information available for managers and strategists to use in innovation, creating customer value, and consequently generating increased profits (Davenport. T., Leibold, M., \& and Voelpel, S., 2006). Adopting this paradigm is essential for 21st century businesses that want to survive, prosper and grow (Kolk, 2007). Researchers have come up with a balanced innovation strategy that includes a clear understanding of the particular business ecosystem and a redesign and 'stretching' of the business model beyond the traditional strategic planning process to include compiling and analysing information from a multitude of sources, modifying operating processes and implementing robust plans (Davenport. T., Leibold, M., \& and Voelpel, S., 2006).

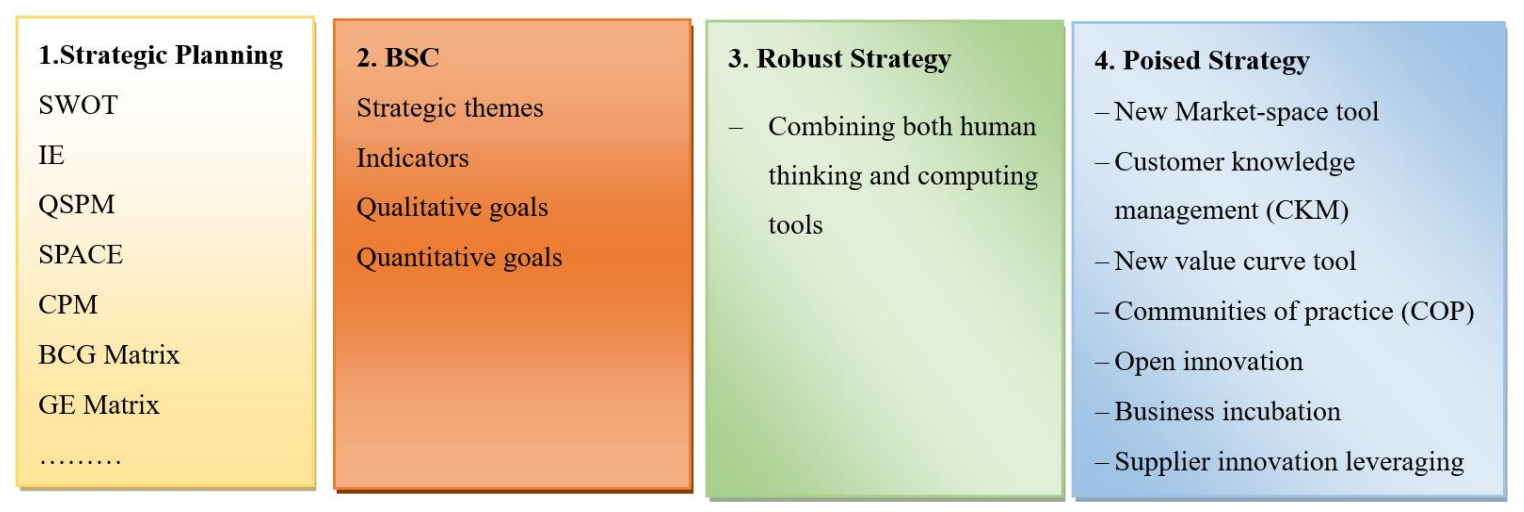

Figure 1. Summarizes the list of techniques used in each step

\section{Research Methods}

\subsection{Application of the Q-method}

The Q method is not as well-known among strategic managers as it should be given its great potential for aiding in the planning process. Although this method has recently been applied in various fields of research in Iran, it still needs time to reach its full power (Barry, John \& Proops, John, 1999). The Q method, which was developed by William 
Stephenson, uses factor analysis in a qualitative research process to acquire the subjective points of view of a set of individuals, including their attitudes, beliefs, and feelings. The Q method is an effective way to gain information from small samples (Rosemary Byrne, Susan Byrne, Ray Ryan, Bernadette O'Regan, 2017) In this method, participants rank a series of statements according to a given algorithm, and then factor analysis is used to establish common patterns (Brown, 1980). One reason for applying this method is to obtain and explore the individuals' viewpoints on a subject. Although factor analysis has been used to classify respondents based on their similar attitudes on specific topics, the Q method can be used to identify the scope and subjective changes in a specific group of people regarding a specific concern (Angelopoulos, 2009).

The Q method provides a framework for systematic research on individual points of view, beliefs, thoughts, and attitudes (Brown, 1993). Traditionally, qualitative methods such as interviews and concentration groups or some quantitative approaches such as questionnaires have been used (Barker, H. Janet, 2008). In testing a research hypothesis, it is essential to obtain accurate data about the participants' attitudes towards specific topics or issues and the Q method provides an excellent way to determine the respondents' points of view (Barker, H. Janet, 2008). Brown (1986) states that there are no other methods or theories comparable in applicability to the Q method. At the time when the method was first introduced, it was considered a bonanza of opportunity for researchers. The method was reinstated in the United States in the 1970s and in the 1990s, which led to an increased interest in subjective reviews and a reduced commitment to objective research (Barker, H. Janet, 2008).

The $\mathrm{Q}$ method is a combination of qualitative (the process of collecting comments) and quantitative (exploratory factor analysis) approaches.

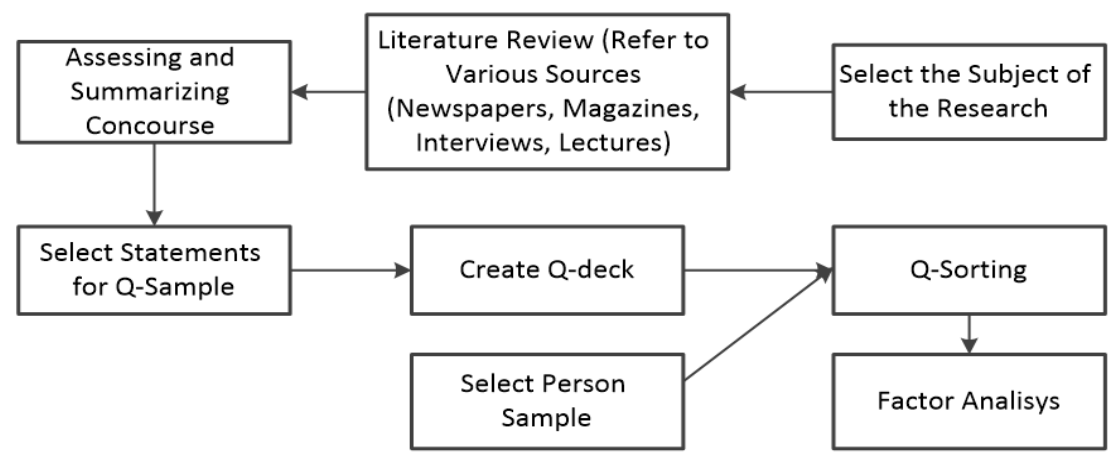

Figure 2. Shows the common Q method steps

\subsection{Subjects for Research}

Appropriate subjects for application of the Q method are those expected to generate a diversity of opinions among experts. In this paper, the research subject was why managers did not use available advanced strategic management techniques for planning in Iranian organizations.

\subsection{The Scope of Discourse}

The statements in the discourse space were collected from primary and secondary sources. Sixty-eight terms were acquired by examining the literature in the field of strategic business planning as well as by interviewing experts on the subject.

\subsection{Choosing Statements for the Discourse Space}

The statements in the discourse space can be very short or relatively long. There can be duplications or items less relevant to our research so that it is not necessary to apply all of them in the Q study. A representative sample of statements divided into structured and non-structured groups that reflect the various dimensions of the discourse space are all that is needed to initiate a $\mathrm{Q}$ study. Regarding the minimum number of statements, Angelopoulos has indicated that 30 to 100 would be adequate (Angelopoulos, 2009), but usually, between 50 and 70 statements are selected. Barker stated that the number of suitable phrases should be 60 to 90 for the outcomes to be valid (Barker, H. Janet, 2008), while Brown (1980) considered a sufficient number of statements for a Q study to be 40 to 60 (Brown, 1980). In this phase of our study, 68 extracted statements were reviewed by six experts to confirm that they were clear and concise. 
From this total, 43 key statements were selected based on the experts' opinions as definitive for our Q study. The valid statements were all chosen to add different dimensions to the subject and were given a final, careful review by the experts to ensure accuracy. Reliability is also measurable in the Q method by various statistical tests such as Cronbach's alpha, which we used in this research. The value for Cronbach's alpha in this study was 0.886 , which illustrates the high reliability of the Q statements and the results of their sorting in the Q method. The Q statements for this study are listed in Table 2 .

Table 2. Q method statements

\begin{tabular}{|c|c|}
\hline Row & Q Statements \\
\hline 1 & The lack of strategic education and managers are unfamiliar with the new strategic concepts. \\
\hline 2 & Mistrust of the managers of the organization regarding the new strategic management techniques. \\
\hline 3 & Lack of time to address the strategic issues. \\
\hline 4 & Possessing the unprofessional team to apply advanced strategic management techniques. \\
\hline 5 & $\begin{array}{l}\text { The lack of interest and commitment of executives to the implementation of modern strategic management } \\
\text { techniques. }\end{array}$ \\
\hline 6 & Not identifying the staff training requirements and providing inadequacy training. \\
\hline 7 & The reluctance of employees to participate in the implementation of new strategic management models. \\
\hline 8 & Unprofessional employees in employing modern strategic management tools and techniques. \\
\hline 9 & Not possessing the information systems to apply the latest strategic management techniques. \\
\hline 10 & Lack of successful patterns of practicing modern strategic management techniques in Iran. \\
\hline 11 & $\begin{array}{l}\text { Lack of qualified experts to provide appropriate approaches for using modern strategic management } \\
\text { techniques. }\end{array}$ \\
\hline 12 & Lack of proper culture in the organization in order to use modern strategic management tools. \\
\hline 13 & $\begin{array}{l}\text { Insufficient expertise and practical experience among executives to select the best strategic management } \\
\text { tools. }\end{array}$ \\
\hline 14 & Key stakeholders' representatives do not support to employ new strategic management techniques. \\
\hline 15 & Inadequate budget allocation to provide the necessary prerequisites for applying these techniques. \\
\hline 16 & $\begin{array}{l}\text { Insufficient knowledge resources and practical training (such as workshops) for managers to apply new } \\
\text { techniques. }\end{array}$ \\
\hline 17 & The average short-term management experience in Iranian organizations. \\
\hline 18 & $\begin{array}{l}\text { There are not any lines and principles of guidance for the utilization of modern strategic management } \\
\text { techniques. }\end{array}$ \\
\hline 19 & $\begin{array}{l}\text { Managers could not access the information of successful Iranian companies in using these techniques due to } \\
\text { a lack of transparency in the competitive market. }\end{array}$ \\
\hline 20 & Inappropriate IT infrastructure to use the latest strategic management techniques. \\
\hline 21 & The organization's executives fear the failure of using the latest strategic management techniques and tools. \\
\hline 22 & Fears of the inability to establish a relationship between a modern strategic plan with operational programs. \\
\hline 23 & There are not any essential tools to encourage employees and motivate them to utilize new techniques. \\
\hline 24 & $\begin{array}{l}\text { There is not any effective inter-organizational communication between different levels of the organization to } \\
\text { clarify the responsibilities and activities of the staff in using the updated techniques. }\end{array}$ \\
\hline 25 & The complexity of modern strategic management techniques and tools. \\
\hline 26 & $\begin{array}{l}\text { These techniques and tools Emphasize on futures studies, knowledge and lack of attitude of managers in the } \\
\text { organization. }\end{array}$ \\
\hline 27 & The lack of appropriate leadership style in the organization. \\
\hline
\end{tabular}




\begin{tabular}{|c|c|}
\hline 28 & Destructive competitive activities among organizational units. \\
\hline 29 & Inappropriate control and evaluation systems in the organization. \\
\hline 30 & Fear of changing a previous business model by applying new techniques. \\
\hline 31 & The lack of strategic management expertise in the organization using new strategic management techniques. \\
\hline 32 & The desire of executives to execute the traditional approach and strategic management techniques. \\
\hline 33 & There is not any strategic thinking for executives of companies. \\
\hline 34 & There is not any previous experience in using modern strategic management techniques. \\
\hline 35 & An absence of uncertainty in many industries. \\
\hline 36 & Being family-based in Iranian companies and their dominant thinking. \\
\hline 37 & $\begin{array}{l}\text { No requirements for the use of modern strategic management tools due to the initial problems in many } \\
\text { companies. }\end{array}$ \\
\hline 38 & $\begin{array}{l}\text { The inability of senior strategist leaders to detect a problem and to use traditional similar models in different } \\
\text { organizations. }\end{array}$ \\
\hline 39 & $\begin{array}{l}\text { The organization's resilience in switching from the traditional approach to modern strategic management } \\
\text { tools. }\end{array}$ \\
\hline 40 & $\begin{array}{l}\text { The inability of organizations to adapt to the changes in the challenging environment as a prerequisite for } \\
\text { new strategic management tools. }\end{array}$ \\
\hline 41 & Improper organizational structure to support new strategic management models. \\
\hline 42 & The high cost of data collection, usage of expert human resources, and usage of expert advisors. \\
\hline 43 & Lack of consensus among senior decision-makers in order to use new strategic management techniques. \\
\hline
\end{tabular}

\subsection{Sorting $Q$ Samples}

The validated $\mathrm{Q}$ sample statements were reviewed and edited to be unambiguous for participants. Then, the respondents in this study read the statements and carried out the Q- sorting exercise online by using 'Q-Sortware', a web-based program developed by Dr. Alessio Pruneddu (http://qsortware.net/).

\subsection{Selecting the Respondents}

The number of individuals needed to participate in a particular Q method procedure depends on a set of criteria. Mckeown and Thomas stated that the nature and purpose of the $\mathrm{Q}$ method was a determining factor in calculating the minimum number of respondents required for a study (Mckeown, 1998). In a study such as ours, we were seeking to find a wide variety of views on the question, so 50 to 100 respondents were required to execute the $\mathrm{Q}$ sorting based on the given instructions. If we had been seeking to deeply examine a subject from a variety of angles, only one respondent would have been enough to arrange the statements. The group of people for this study were purposefully selected from among managers, Iranian consultants and university professors who are experts in strategy concepts. Targeting people who have related knowledge about the subject is the usual method, but the patterns of factor analysis in statistic concepts can also be utilized.

\subsection{Sorting Q Statements}

Q sorting is a technique for compiling Q data; but prior to the introduction of the $\mathrm{Q}$ method, other sorting techniques were also used to organize data (Rosemary Byrne, Susan Byrne, Ray Ryan, Bernadette O'Regan, 2017). After the researcher has defined each statement, the respondents read them carefully, determine the appropriate rank for each statement, and place it on a chart. Statements are distributed in an optional or compulsory manner. In compulsory distribution, participants are asked to use a specific algorithm in which the number of statements is specified for each rank, which are completely represented on the chart. In an optional distribution, participants have more freedom for sorting. The distribution of the statement is not known ahead of time and each participant creates it himself. The compulsory distribution was chosen for this study (Fig. 3) and instructions explaining how the statements should be sorted were provided to the participants. 


\begin{tabular}{|l|l|l|l|l|l|l|l|l|}
\hline 4 & 3 & 2 & 1 & 0 & -1 & -2 & -3 & -4 \\
\hline & & & & & & & & \\
\hline & & & & & & & & \\
\hline & & & & & & & & \\
\hline
\end{tabular}

Figure 3. Q chart

The instructions and manuals need to be provided and explained how the statements require to be sorted by the participants.

\subsection{Statistical Analysis}

Statistical analysis of the data is carried out using factor analysis, which is the main statistical technique for the Q method. After performing the factor analysis, extracting the factors, and obtaining significant factor loadings, the key factors should be precisely interpreted.

\section{Results}

Table 3. Participant demographics

\begin{tabular}{lll}
\hline Index & Description & Values \\
\hline Sex & Female & $16.3 \%$ \\
\cline { 2 - 3 } & Male & $83.7 \%$ \\
\hline Everage age & & 39.9 \\
\cline { 2 - 3 } & Ph.D. & $32.5 \%$ \\
\cline { 2 - 3 } & Master's degree & $53.4 \%$ \\
\cline { 2 - 3 } & Bachelor's degree & $9.3 \%$ \\
\cline { 2 - 3 } Role in Organization & High school & $4.8 \%$ \\
\cline { 2 - 3 } & Board of Directors & $9.2 \%$ \\
\cline { 2 - 3 } & CEO & $23.3 \%$ \\
\cline { 2 - 3 } & Consultant & $23.3 \%$ \\
\cline { 2 - 3 } & Senior Manager & $20.9 \%$ \\
\cline { 2 - 3 } & Manager & $23.3 \%$ \\
\hline
\end{tabular}

The factor analysis process in the Q method consists of two phases: extracting the factors and interpreting them. The main component of the process is the factor extraction method. In the second step, the Varimax method for rotational agents was used. The variance table indicates that the $\mathrm{Q}$ method detected twelve factors (special values $>1$ ), and these twelve factors described and covered about $80 \%$ of the variance (Table 4 ).

Table 4. ANOVA

\begin{tabular}{lllllll}
\hline Rows & \multicolumn{2}{l}{$\begin{array}{l}\text { Sum Square of Loading } \\
\text { (Factor Analysis) }\end{array}$} & & $\begin{array}{l}\text { Sum of Square of Rotated Loading } \\
\text { (Factor Analysis) }\end{array}$ \\
\cline { 2 - 7 } & Total & Variance (\%) & $\begin{array}{l}\text { Cumulative } \\
\text { Percentage }\end{array}$ & Total & Variance (\%) & $\begin{array}{l}\text { Cumulative } \\
\text { Percentage }\end{array}$ \\
\hline 1 & 8.14 & 18.934 & 18.934 & 4.365 & 10.152 & 10.152 \\
\hline 2 & 4.05 & 9.413 & 28.346 & 3.918 & 9.113 & 19.265 \\
\hline 3 & 3.78 & 8.785 & 37.132 & 3.68 & 8.557 & 27.822 \\
\hline 4 & 2.91 & 6.759 & 43.89 & 3.177 & 7.388 & 35.211 \\
\hline 5 & 2.77 & 6.432 & 50.322 & 3.048 & 7.089 & 42.299 \\
\hline
\end{tabular}




\begin{tabular}{lllllll}
\hline 6 & 2.52 & 5.866 & 56.188 & 2.91 & 6.768 & 49.067 \\
\hline 7 & 2.35 & 5.457 & 61.645 & 2.472 & 5.748 & 54.816 \\
\hline 8 & 1.97 & 4.586 & 66.231 & 2.264 & 5.265 & 60.081 \\
\hline 9 & 1.77 & 4.118 & 70.348 & 2.264 & 5.265 & 65.346 \\
\hline 10 & 1.53 & 3.566 & 73.915 & 2.221 & 5.164 & 70.51 \\
\hline 11 & 1.34 & 3.123 & 77.038 & 2.072 & 4.818 & 75.328 \\
\hline 12 & 1.29 & 2.999 & 80.037 & 2.025 & 4.709 & 80.037 \\
\hline
\end{tabular}

To interpret and identify similar factors, a rotating matrix was used (Table 5). This matrix allowed us to identify which of the respondents made any of the factors or patterns. For this purpose, the significance of factors has been investigated. If the absolute value of the factor load is $>\frac{1.96}{\sqrt{n}}$, then it can be said that the load is a meaningful factor at the $95 \%$ confidence level. In this study, the number of Q cards was 43, therefore, factor loadings $>0.299$ were $95 \%$ reliable.

Table 5. Rotational factors matrix

\begin{tabular}{|c|c|c|c|c|c|c|c|c|c|c|c|c|}
\hline \multirow[t]{2}{*}{ Respondents } & \multicolumn{12}{|c|}{ Factors } \\
\hline & 1 & 2 & 3 & 4 & 5 & 6 & 7 & 8 & 9 & 10 & 11 & 12 \\
\hline 37 & -0.83 & 0.15 & & & -0.25 & & & & -0.17 & & & 0.16 \\
\hline 36 & -0.80 & 0.27 & & & & & & -0.11 & & & & 0.13 \\
\hline 22 & 0.70 & & & 0.29 & 0.14 & 0.12 & & & 0.26 & & & 0.37 \\
\hline 38 & -0.68 & -0.11 & -0.34 & & -0.26 & & & 0.19 & & & -0.18 & -0.10 \\
\hline 35 & -0.64 & 0.41 & & -0.22 & & -0.15 & & -0.27 & & & -0.22 & 0.24 \\
\hline 21 & 0.51 & -0.21 & 0.16 & & & & -0.25 & -0.21 & 0.20 & 0.16 & -0.24 & 0.42 \\
\hline 32 & -0.19 & 0.80 & & -0.22 & -0.15 & -0.15 & & 0.18 & & 0.15 & & \\
\hline 33 & -0.29 & 0.78 & -0.13 & -0.22 & & & & -0.11 & 0.17 & 0.15 & & \\
\hline 31 & -0.16 & 0.68 & 0.11 & & 0.10 & & -0.22 & -0.14 & -0.27 & & -0.29 & \\
\hline 19 & & -0.66 & 0.16 & & 0.22 & 0.12 & 0.20 & -0.28 & & 0.26 & 0.11 & \\
\hline 18 & 0.11 & -0.65 & 0.44 & -0.17 & 0.18 & -0.21 & -0.22 & & -0.29 & & & \\
\hline 43 & & 0.10 & -0.88 & & & -0.12 & -0.13 & & & & & \\
\hline 42 & & & -0.87 & & & & & -0.13 & & & & \\
\hline 39 & & 0.20 & -0.57 & -0.45 & -0.37 & -0.12 & & 0.30 & & & & \\
\hline 41 & -0.11 & & -0.56 & & -0.49 & & & & -0.53 & & & 0.13 \\
\hline 30 & 0.18 & 0.13 & 0.23 & -0.74 & & 0.35 & -0.30 & & 0.11 & & & \\
\hline 25 & 0.21 & & 0.21 & 0.71 & & 0.23 & -0.34 & & & -0.14 & 0.10 & \\
\hline 23 & 0.60 & -0.27 & & 0.63 & & & & & & & & \\
\hline 24 & 0.47 & -0.21 & 0.21 & 0.57 & & 0.29 & & -0.10 & & & 0.16 & 0.18 \\
\hline 17 & 0.25 & -0.28 & 0.30 & -0.46 & 0.19 & & 0.28 & & & 0.32 & 0.32 & 0.18 \\
\hline 14 & 0.17 & & & & 0.81 & & & & & -0.15 & 0.31 & \\
\hline 40 & -0.19 & 0.13 & -0.34 & & -0.70 & & 0.12 & 0.21 & -0.38 & -0.18 & & \\
\hline 12 & 0.11 & -0.16 & 0.16 & & 0.56 & & 0.23 & 0.39 & & & & 0.22 \\
\hline 9 & & & -0.30 & 0.18 & 0.52 & & 0.44 & & 0.15 & -0.15 & -0.33 & \\
\hline 15 & 0.28 & -0.26 & -0.23 & & 0.47 & & -0.19 & 0.41 & & -0.11 & 0.32 & \\
\hline 28 & & & & & & 0.83 & & & -0.13 & 0.17 & & -0.17 \\
\hline 27 & 0.21 & & 0.14 & -0.18 & & 0.69 & 0.17 & & 0.14 & 0.31 & -0.16 & 0.19 \\
\hline 26 & 0.13 & & 0.14 & 0.31 & & 0.69 & -0.18 & & & -0.18 & -0.18 & 0.29 \\
\hline 8 & 0.22 & 0.26 & 0.22 & 0.18 & & -0.56 & 0.47 & & -0.13 & & -0.33 & 0.11 \\
\hline 10 & & -0.13 & 0.15 & -0.12 & & & 0.81 & & & & & \\
\hline 2 & -0.11 & 0.11 & 0.20 & & -0.21 & -0.15 & 0.48 & 0.34 & 0.35 & 0.24 & 0.21 & \\
\hline 34 & -0.28 & 0.29 & -0.31 & -0.21 & -0.28 & -0.28 & -0.35 & & -0.20 & 0.26 & -0.18 & \\
\hline 6 & & & 0.32 & & & & -0.23 & 0.77 & 0.22 & 0.17 & & \\
\hline 20 & & -0.42 & & 0.12 & & & -0.24 & -0.70 & & & -0.18 & \\
\hline 1 & 0.21 & 0.17 & 0.14 & & & & & 0.14 & 0.86 & & & \\
\hline 7 & 0.18 & 0.18 & & & -0.10 & -0.42 & 0.17 & & -0.60 & 0.12 & -0.19 & -0.42 \\
\hline 5 & & & 0.16 & & & & & 0.14 & & 0.81 & & \\
\hline 11 & -0.10 & -0.35 & 0.24 & 0.18 & & -0.16 & 0.11 & & & -0.73 & & \\
\hline 29 & & & 0.18 & -0.40 & -0.16 & 0.36 & & -0.23 & 0.12 & 0.52 & & \\
\hline 16 & 0.18 & -0.21 & & 0.10 & & -0.23 & -0.15 & & & & 0.77 & 0.11 \\
\hline 13 & & & 0.24 & & 0.44 & & 0.31 & & & & 0.66 & -0.13 \\
\hline 4 & 0.11 & & 0.12 & -0.22 & & & 0.12 & & 0.15 & & & -0.82 \\
\hline 3 & & & 0.21 & 0.41 & & & -0.24 & 0.35 & -0.17 & -0.16 & & -0.61 \\
\hline
\end{tabular}




\section{Discussion}

By applying the Q method in this study, twelve different perspectives were identified and the most important factors in each of these patterns are listed in the following table:

Table 6. The twelve perspectives of Iranian managers for not applying modern strategic planning methods

\begin{tabular}{|c|c|c|c|}
\hline Rows & Group & Views & Factors \\
\hline 1 & $\begin{array}{l}\text { Willing to keep } \\
\text { status current }\end{array}$ & status current & $\begin{array}{l}\text { - Inability of strategists to see the problem with applying traditional } \\
\text { approaches in different organizations. } \\
\text { - The organization's resilience in switching from the traditional approach } \\
\text { of strategic management to modem strategic management tools. } \\
\text { - Lack of consensus among decision-makers in trying new strategic } \\
\text { management techniques. }\end{array}$ \\
\hline 2 & $\begin{array}{l}\text { Willing to keep the } \\
\text { traditional attitude }\end{array}$ & $\begin{array}{c}\text { the traditional } \\
\text { attitude }\end{array}$ & $\begin{array}{l}\text { - Emphasis on new strategic management techniques for future studies } \\
\text { and lack of positive attitude towards managers of the organization. } \\
\text { - Lack of strategic thinking (thorough thinking) by executives of } \\
\text { companies } \\
\text { - Being the dominant Iranian companies and thinking about them }\end{array}$ \\
\hline 3 & $\begin{array}{l}\text { Absence of readiness } \\
\text { for the organization }\end{array}$ & $\begin{array}{l}\text { Lack of } \\
\text { readiness }\end{array}$ & $\begin{array}{l}\text { - Lack of proper culture in the organization for implementing modem } \\
\text { strategic management models } \\
\text { - Lack of guidelines for using modem strategic management techniques. } \\
\text { - Executives' fears of failure in using the latest strategic management } \\
\text { techniques. }\end{array}$ \\
\hline 4 & $\begin{array}{c}\text { The lack of modem } \\
\text { tools }\end{array}$ & $\begin{array}{l}\text { Not requirment } \\
\text { any new new } \\
\text { tools }\end{array}$ & $\begin{array}{l}\text { - Lack of guidelines for using modem strategic management techniques. } \\
\text { - Uncertainty in many industries, resulting in the feeling that using } \\
\text { modern strategic management tools is umecessary } \\
\text { - Lack of an appropriate organizational structure to support new strategic } \\
\text { management models }\end{array}$ \\
\hline 5 & $\begin{array}{l}\text { Infrastructure } \\
\text { weakness }\end{array}$ & $\begin{array}{l}\text { Infrastructure } \\
\text { weakness }\end{array}$ & $\begin{array}{l}\text { - Lack of guidelines for using modem strategic management techniques. } \\
\text { - No appropriate IT infrastructure to employ the latest strategic } \\
\text { management techniques. } \\
\text { - Fear of the inability to establish a relationship between strategic plans } \\
\text { developed by modem strategic management techniques with operational } \\
\text { plans }\end{array}$ \\
\hline 6 & $\begin{array}{c}\text { The weakness in } \\
\text { solving basic } \\
\text { problems }\end{array}$ & $\begin{array}{l}\text { Weakness in } \\
\text { solving basic } \\
\text { problems }\end{array}$ & $\begin{array}{l}\text { - Lack of expertise and practical experience among executives to select } \\
\text { the latest strategic management tools. } \\
\text { - Unavailability of guidelines for using modem strategic management } \\
\text { techniques. } \\
\text { - Initial problems in many companies identifying the requirements for } \\
\text { applying modem strategic management tools. }\end{array}$ \\
\hline 7 & Disappointing from & Uncertainty & - Mistrust of management to use the new strategic management \\
\hline
\end{tabular}




\begin{tabular}{|c|c|c|c|}
\hline & new tools & about tools & $\begin{array}{l}\text { techniques properly. } \\
\text { - Unwillingness of employees to participate in the implementation of new } \\
\text { strategic management models } \\
\text { - Lack of effective inter-organizational communication between different } \\
\text { levels of the organization to demonstrate the staff responsibilities and } \\
\text { activities regarding modem strategic management techniques. }\end{array}$ \\
\hline 8 & $\begin{array}{l}\text { Unwilling managers } \\
\text { to try new tools }\end{array}$ & $\begin{array}{l}\text { managers } \\
\text { Reluctant }\end{array}$ & $\begin{array}{l}\text { - Lack of relevant education and managers' unfamiliarity with new } \\
\text { strategic management issues. } \\
\text { - Lack of interest and commitment of executives in using modem strategic } \\
\text { management techniques. } \\
\text { - Unwillingness of employees to participate in the implementation of new } \\
\text { strategic management models. }\end{array}$ \\
\hline 9 & Indifferent managers & $\begin{array}{l}\text { Indifferent } \\
\text { managers }\end{array}$ & $\begin{array}{l}\text { - Lack of interest and commitment of executives in using modem strategic } \\
\text { management techniques. } \\
\text { - Short-term management in Iranian organizations and their inability to } \\
\text { use modern strategic management techniques. } \\
\text { - The desire of executives to use traditional techniques for strategic } \\
\text { management with a retrospective approach }\end{array}$ \\
\hline 10 & $\begin{array}{l}\text { The lack of executive } \\
\text { ability }\end{array}$ & $\begin{array}{c}\text { Lack of } \\
\text { executive power }\end{array}$ & $\begin{array}{l}\text { - Lack of ability among employees in using modern strategic management } \\
\text { tools. } \\
\text { - High cost of data collection, expert human resources, and working with } \\
\text { expert advisers } \\
\text { - Lack of consensus among senior decision-makers in using new strategic } \\
\text { management techniques. }\end{array}$ \\
\hline 11 & $\begin{array}{l}\text { inaccessibility of a } \\
\text { successful model }\end{array}$ & $\begin{array}{l}\text { No Successful } \\
\text { Pattem }\end{array}$ & $\begin{array}{l}\text { - Lack of successful pattems using modem strategic management } \\
\text { techniques. } \\
\text { - Lack of knowledge and practical training resources such as workshops } \\
\text { for managers to use new strategic management techniques. } \\
\text { - Lack of appropriate leadership style in the organization in order to use } \\
\text { new strategic management techniques. }\end{array}$ \\
\hline 12 & $\begin{array}{l}\text { not having enough } \\
\text { resources }\end{array}$ & $\begin{array}{l}\text { Lack of } \\
\text { resource }\end{array}$ & $\begin{array}{l}\text { - Not enough time to address the issue } \\
\text { - Lack of knowledge and practical training resources such as workshops } \\
\text { for managers to use new techniques for strategic management } \\
\text { - The dominant Iranian companies have been managed by family } \\
\text { members with unique views }\end{array}$ \\
\hline
\end{tabular}

\subsection{Perspectives}

The twelve subjective patterns are listed in Table 6 which give the reasons for not employing modern strategic management techniques.

First viewpoint (stay in current status): This perspective describes managers who are reluctant to change the current situation. This group usually does not have the ability to identify the organization's issues accurately and try to use repetitive techniques. However, applying modern strategy management techniques will not be effective in all matters, and the appropriate tool and technique should be used according to the problem. Therefore, this group of executives does not agree with other decision-makers who are willing to use modern tools and techniques.

Second viewpoint (traditional attitude): This group usually includes the owners of family-owned businesses. These managers are reluctant to use modern strategic management tools and techniques because they think that they are related to a future-based approach with a high degree of uncertainty. 
Third Viewpoint (lack of readiness): These managers believe that their organization lacks a suitable platform for using the latest strategic management techniques and tools. They believe that the lack of a proper organizational culture, as well as guidance, training resources, and workshops in the organization, will result in failure to utilize the new tools and techniques of strategic management.

The Fourth Viewpoint (no requirement for new tools): These executives are active in industries with low uncertainty or operate in companies having an inappropriate organizational structure and guidelines. These companies also have insufficient guiding principles to support new strategic management techniques and tools, so they feel uncertain about these techniques and their benefits.

Fifth Viewpoint (infrastructure weakness): This group feels that the weak infrastructure in the organization is a reason for the inability to use new strategic management techniques and tools. They believe inappropriate IT infrastructure and insufficient guidance can make them unsuccessful when using modern strategic management tools, and they are afraid that they will not be able to create a relationship between the strategic plans and the operational plans in their organization.

The sixth Viewpoint (weakness in solving basic problems): This group of managers believes that organizations have always suffered from problems including lack of adequate expertise and practical experience by employees. They insist that the organization first needs to address these problems before spending time and money solving strategic issues.

Seventh Viewpoint (uncertainty about tools): Their views have been shaped by a lack of confidence in using modern strategic management. Therefore, having such managers will deter employees who are interested in using strategic management techniques and tools. Due to such an attitude, these managers are not motivated to improve communication within the organization or to be transparent in defining employee responsibilities in using these tools and techniques.

Eighth Viewpoint (unwilling managers): Due to the lack of relevant education or unfamiliarity with new strategic management topics, these managers are not interested in using modern strategic management tools and techniques, and will not encourage their employees to try these tools.

Ninth Viewpoint (indifferent managers): This group believes that being a CEO in an Iranian organization is a very short-term proposition. Thus, they feel that attempting to employ modern strategic management tools and techniques is a waste of time because strategic management is a time-consuming process and a long-term vision is needed to attain effective results.

Tenth Viewpoint (lack of executive power): This group of executives believes that there are too few skilled staff members to be able to work with the latest strategic management techniques and tools, and that their organization does not have a sufficient budget to hire a strategic expert for employing these tools.

Eleventh Viewpoint (no successful pattern): This group claims that Iranian organizations do not have enough knowledge resources and appropriate leadership style. Very few companies can be found that have succeeded in using the latest strategic management tools and techniques. On the other hand, due to the limited indoor competition in Iran, those few successful companies also refuse to share information about their methods for success.

Twelfth Viewpoint (lack of resources): These managers are often the family owners of a business. This group believes that there is not enough time to address these issues and that there is a lack of knowledge and practical resources to apply modern strategic management tools and techniques.

\section{Conclusions}

This research extends the current literature on implementing strategy management by investigating the barriers to apply them in a developing country. The other contribution is using Q method as a very helpful approach to apprehend the points of view of a group of experts regarding our problem. In this study, the results of the Q method indicated that while the motivations varied, the main reasons why strategic planners failed to utilize modern strategic management tools in Iranian organizations was a combination of lack of expertise and organizational support. In order to clarify and explain these reasons we deployed ANOVA and factors analysis, which led to the identification of twelve viewpoints of senior managers in Iranian companies regarding their decisions not to apply modern strategic management techniques and tools. Based on the results of this analysis, other researchers and strategists should be able to better understand how the various attitudes of their managers affect their decision-making abilities and what to do to improve their performance. Some suggestions are listed below: 
1. Strategic change is a key aspect of organizational planning in the $21^{\text {st }}$ century as it involves extensive and long-term adjustments throughout the organization. Its purpose and vision must mirror the mission of the organization in adapting to future competition, societal needs and new technology. Therefore, it is imperative that business strategists learn to successfully apply the advanced knowledge and human capital approaches, the new tools and technologies that aid in wise decision-making.

2. In the face of dynamic and changing environments, the concerns of senior managers have become increasingly complex. Realizing the need for change, taking the necessary actions, and keeping track of the unpredictable consequences of change has critically increased their responsibilities. For organizations to successfully respond to the needs of their core customers and sustain growth and competitiveness in such an environment, they must create a realistic vision of the future and develop definite strategies ahead of their competitors. Having a good competitive strategy requires modern strategic techniques and tools and the skill to motivate employees and staff to apply them in their jobs.

3. Managers must develop new guidelines and provide comprehensive guidance for their employees to effectively utilize modern strategic management tools and techniques. Once the needed skills and competencies have been defined for the strategic action plans, managers can begin hiring a talented, expert staff who knows how to get the job done. With the specific goal in mind of utilizing the best, cutting-edge tools and strategic methods, an expert workforce can be built up, with knowledgeable, forward-thinking managers at the helm.

4. Creating an advanced IT infrastructure is critical for providing the timely, accurate information so necessary in developing successful business strategies that save time and money, create more efficient operations, and increase customer satisfaction and brand loyalty.

Overall, this study generate important understanding regarding not applying the updated strategy tools in the developing countries and we can enhance the strategy planning by removing or overcoming the barriers.In this research Q method is applying to gather experts views which is an appropriate tool for this study and is first time has been used in stretagy planning researches.

This study has some limitations. For instance, due to time, lack of resources and available strategy expert, this study just limited to one city and one country. It is better we apply our model and method in more developing country to generalize our study. The top mangers or CEOs are not interested to attend this interview; some would generate a meeting, but they would cancel or rescheduale it. Also, CEOs or owners try to not answer questions or give information very clearly, because they though researches would use against them.

Future research can have a sample from across the country and different industry to establish if location and type industry affects application of updated strategic planning tools by firms.

\section{References}

Afonina, A., \& Chalupský, V. (2012). The Current Strategic Management Tools and Techniques: The Evidence From Czech Republic. Economics and Management, 17(4), 1535-1544. https://doi.org/10.5755/j01.em.17.4.3026

Angelopoulos, G. (2009). Q methodology and the measurement of subjectivity in corporate brand perception. S.Afr.J.Bus.Manage, 40(3), 21-33. https://hdl.handle.net/10520/EJC22377.

Barker, H. J. (2008). Q-methodology: An Alternative Approach to Research in Nurse Education. Nurse Education Today, 28, 917-925. https://doi.org/10.1016/j.nedt.2008.05.010

Barry, J., \& Proops, J. (1999). Seeking Sustainability Discourses with Q Methodology. Ecological Economics, 337-345. https://doi.org/10.1016/S0921-8009(98)00053-6

Brown, S. R. (1980). Political Subjectivity: Applications of Q Methodology in Political Science. New Haven: Yale University Press.

Brown, S. R. (1993). A Primer on Q Methodology. Operant Subjectivity, 16(3/4), 91-138.

Byrne, R., Byrne, S., Ryan, R., \& O'Regan, B. (2017). Applying the Q-method to identify primary motivation factors and barriers. Energy Policy, 110, 40-50. https://doi.org/10.1016/j.enpol.2017.08.007

Clark, D. N. (1997). Strategic management tool usage: A comparative study. Strategic Change, (6), 417-427. https://doi.org/10.1002/(SICI)1099-1697(199711)6:7<417::AID-JSC281>3.0.CO;2-9

Daniel, M. H. (2006). Mastering the dynamic nature of modern strategy. Handbook of Business Strategy, 35-40. https://doi.org/10.1108/10775730610618594. 
Davenport. T., Leibold, M., \& and Voelpel, S. (2006). Strategic management in the innovation economy. Harvard University.

Fleisher, G., \& Bensoussan, B. (2003). Strategic and competitive analysis. New Jersey: Prentice Hall.

Frost, F. (2003). The use of strategic tools by small and medium-sized enterprises: An Australasian study. Strategic Change, 12, 49-62. https://doi.org/10.1002/jsc.607

Gibson, R. (1998). Rethinking the future: Rethinking business, principles, competition, control, leadership, markets and the world. London: Nicholas Brealey Publishing. https://doi.org/10.1002/jsc.799

Gunn, R., \& Williams, W. (2007). Strategic tools: An empirical investigation into strategy in practice in the UK. Strategic Change, 16(2), 201-216.

Hamel, G. (2006). The why, what and how of management innovation. Harvard Business Review.

Hammerstein, P., Hagen, E. H., Herz, A. V. M., \& Herzel, H. (2006). Robustness: A key to evolutionary design. Biological Theory, (1), 90-93.

Henderson, B. D. (1989). The origin of strategy: What business owes Darwin and other reflections on competitive advantage dynamics. Harvard University Review, 2-18.

Kaplan, R. S. (2010). Conceptual foundations of the balanced scorecard. Handbook of Management Accounting Research. https://doi.org/10.1016/S1751-3243(07)03003-9

Kaplan, R. S., \& Norton, D. (2008). Developing the strategy: Vision, value gaps and analysis. Harvard Business School Publishing.

Kaplan, R., \& Norton, D. (2006). Linking Strategy and Planning to Budgets. BSR.

Kaye, M. (1996). Myth-Makers and Story-Tellers. Sydney. Business and Professional Publishing. https://www.jstor.org/stable/40243510

Kiran, D. (2017). Total Quality Management: Key Concepts and Case Studies. New York: Elsevier Inc.

Knott, P. (2006). Typology of strategy tool applications. Management Decision Journal, 44(8), 1090-1105. https://doi.org/10.1108/00251740610690630

Kohli, A. K., \& Jaworski, B. J. (1990). Market orientation: The construct, research propositions, and managerial implications. The Journal of Marketing, 45(2), 1-18. https://doi.org/10.1177/002224299005400201

Kolk, A. (2007). Developing dynamic capabilities and open innovation strategies for corporate growth. Helsinki University of technology, Institute of strategy and international business.

Laamanen, T. (2017). Reflecting on the past 50 years of Long Range Planning and a research agenda for the next 50. Long Range Planning, 1-7. https://doi.org/10.1016/j.lrp.2017.02.001

Lempert, R. J., \& Collins, M. T. (2007). Managing the risk of uncertain threshold response: Comparison of robust, optimum and precautionary approaches. Risk Anal, $27(4), \quad$ 1009-1026. https://doi.org/10.1111/j.1539-6924.2007.00940.x

Lempert, R. J., Popper, S. W., \& Bankes, S. C. (2010). Robust Decision Making: Coping with Uncertainty. The Futurist.

Lempert. R. J., Popper. S. W., \& Bankes, S. C. (2003). Shaping the next one hundred years: New methods for quantitative long-term policy analysis. Rand.

Majama, N. S., \& Magang, T. I. (2017). Strategic Planning in Small and Medium Enterprises (SMEs): A Case Study of Botswana SMEs. Journal of Management and Strategy, 1-30. https://doi.org/10.5430/jms.v8n1p74

Mckeown, B. T. (1998). Q Methodology: Quantitative Applications in the Social. California: 66 Sage Publications.

Miles, M. P., White, J. B., \& Munilla, L. S. (1997). Strategic planning and agribusiness: an exploratory study of the adoption of strategic planning techniques by co-operatives. British Food Journal, 99(11), 401-408. https://doi.org/10.1108/00070709710196481

Mintzberg, H. (2007). Tracking strategies: Toward a general theory. Oxford University Press.

Mintzberg, H., Ahlstrand, B., \& Lampel, J. (1998). Strategy Safari - A Guided Tour.

Oboreh J. S., \& Umukoro, F. G. (2011). Determining the impact of environmental characteristics and uncertainty on the strategic plans of corporate organizations. Sacha Journal of Environmental Studies, 1(1), 31-40. Retrieved 
from https://ssrn.com/abstract=1824622

Okumus, F. (2003). A framework to implement strategies in organization. Management Decisions, 41(9), 871-882. https://doi.org/10.1108/00251740310499555

Pina e Cunha, M., \& Vieira da Cunha, J. (2006). Towards a complexity theory of strategy management decision. Harward Reviews.

Porter, M. E. (1996). What is strategy?. Harvard Business Review.

Ramanujam, V., Venkatraman, N., \& Camillus, J. (1986). Multi-objective assessment of effectiveness of strategic planning: A discriminant analysis approach. Academy of Management Review, 29(2), 347-372. https://doi.org/10.5465/256192

Rigby, D. (2001). Management tools and techniques: A survey. California Management Review, 43(2), $139-159$.

Rigby, D. (2005). Putting tools to the test: senior executives' rate 25 top management tools. Strategy \& Leadership, 29(3), 4-12. https://doi.org/10.1108/10878570110396086

Stenfors, S., Tanner, L., \& Haapalinna, I. (2004). Executive Use of Strategy Tools: Building Shared Understanding through Boundary Objects. Frontiers of E-Business Research, 635-645.

Vuorinen, T., Hakala, H., Kohtamaki, M., \& Uusitalo, K. (2017). Mapping the landscape of strategy tools: A review on strategy tools published in leading journals within the past 25 years. Long Range Planning, 1-20.

Webster, J. L., Reif, W. E., \& Bracker, J. S. (1989). The Manager's guide to strategic planning tools and techniques. Strategy \& Leadership, 17(6), 4-48.

Wright, R. P., et al. (2013). How Useful Are the Strategic Tools We Teach in Business Schools?. Journal of Management Studies, 50. https://doi.org/10.1111/j.1467-6486.2012.01082.x

Zacksenhouse, M., Holmes, P., \& Bogacz, R. (2008). Robust versus optimal strategies for determining the speed-accuracy tradeoff on two-alternative forced choice tasks. https://doi.org/10.1016/j.jmp.2009.12.004. 